\title{
Miejsce procesu cywilnego w systematyce prawa rzymskiego
}

\section{Wprowadzenie}

Dodejmowanie tematu rzymskiego procesu cywilnego i jego miejsca w systematyce prawa rzymskiego wiąże się z ukazaniem katalogu kwestii, mających niejednokrotnie charakter kontrowersyjny. W pierwszej kolejności nasuwa się pytanie o definicję procesu cywilnego oraz wiążące się z nią kwestie terminologiczne. W romanistycznej literaturze przedmiotu obok pojęcia „proces cywilny" spotykamy bowiem także inne, używane z nim zamiennie określenia, o podobnym zakresie i znaczeniu: „proces prywatny”, „ochrona praw prywatnych”, „postępowanie sądowe cywilne”. Celowe wydaje się zatem przedstawienie przedmiotowej siatki pojęciowej, z uwzględnieniem jej strony ewolucyjnej. Należałoby także zapytać, jaka była pozycja norm procesowych w antycznym państwie rzymskim i w jaki sposób Rzymianie postrzegali ich miejsce w systemie prawa? Jakiego typu relacja łączyła cywilny proces rzymski z prawem dziś rozumianym jako materialne? W jakim kierunku przebiegał historyczny rozwój w tym zakresie? Należy także zauważyć występowanie w procedurze cywilnej zarówno elementów o charakterze publicznym, jak i prywatnym, przy tej zaś okazji nasuwa się wątpliwość dotycząca ewentualnej symetrii, czy równowagi pomiędzy tymi czynnikami. Trzeba tu mieć na względzie fakt, że rzymski proces cywilny nie był statyczny i przechodził różne etapy historycznego rozwoju. Odpowiedź na pytanie: czy rzymski proces cywilny był bardziej publiczną czy raczej prywatną procedurą, nie będzie zapewne zatem jednoznaczna. Trzeba także na koniec rozważyć, czy należy rzymski sposób myślenia o procesie cywilnym

\footnotetext{
* Dr Bożena Anna Czech-Jezierska - Katolicki Uniwersytet Lubelski Jana Pawła II, Katedra Administracyjnego Prawa Gospodarczego, Instytut Administracji, Wydział Prawa, Prawa Kanonicznego i Administracji; e-mail: bczechjez@kul.pl
} 
przełożyć na metodę przedstawiania współczesnym studentom tego działu prawa rzymskiego, żeby osiągnąć u nich pożądany efekt kształceniowy. Gaius, z racji, jak należy sądzić, dydaktycznych, wyodrębnił w swym podręczniku prawo dotyczące powództw - ius quod ad actiones pertinet. Dzisiaj wszystkie podręczniki do nauki prawa rzymskiego prywatnego zawierają wydzieloną część poświęconą prawu procesowemu, pozostaje jednak kwestia - lepiej, kiedy jest ona umieszczona, tak jak w „Instytucjach” Gaiusa na końcu, czy też może na początku podręcznika?

Prezentowany artykuł, w zamierzeniu autorki, ma za zadanie jedynie zasygnalizować istnienie katalogu zagadnień, związanych z tematyką miejsca procesu cywilnego w systematyce prawa rzymskiego. $Z$ racji na fundamentalne różnice pomiędzy postępowaniami zwyczajnymi i nadzwyczajnym, których, $\mathrm{z}$ racji na ramy publikacji, nie sposób przedstawić kompleksowo, większość przedstawionych rozważań oparto na rzymskim procesie formułkowym, który odzwierciedla pełen rozkwit myśli prawnej jurysprudencji rzymskiej².

\section{Terminologia}

W związku ze znaną niechęcią Rzymian do konstruowania terminów i teorii jurydycznych, proces cywilny nie doczekał się ujęcia w definicję, aczkolwiek samo jego pojęcie było znane. Był on odróżniany od procesu karnego oraz od postępowania administracyjnego ${ }^{3}$. Rzymskie podejście do prawa procesowego

${ }^{2} \mathrm{~W}$ metodzie wykładu prawa rzymskiego proces formułkowy zajmuje niewątpliwie szczególne miejsce. K. Kolańczyk podkreślał, że jego misternie ukształtowane mechanizmy budzą zasłużony podziw oraz, że to w szczególności dzięki niemu student może najlepiej poznać subtelności postępowania sądowego. K. Kolańczyk, Über den Bildungswert der römischen Zivilprozesslehre für den sozialistischen Juristen, [w:] „Acta Univ. Szegediensis. Acta Juridica et Politica”, t. XXVII, z. 22, Szeged 1970, s. 292-293; por. M. Kaser, K. Hackl, Das römische Zivilprozessrecht (zweite Aufl.), München 1996, s. 5.

3 W. Litewski, Rzymski proces cywilny, Kraków 1988, s. 9 i 104; M. Kaser, K. Hackl, op. cit., s. 2: W państwie rzymskim granica między procesem karnym a cywilnym przebiegała nieco inaczej, niż współcześnie, ponieważ delicta privata należały do prawa prywatnego i procesu cywilnego. Poszkodowanemu z deliktu przysługiwała actio poenalis o zapłatę grzywny, dochodzona w procesie cywilnym. Na przełomie III i II wieku p.n.e. rozwinęło się odrębne sądownictwo karne dla ciężkich przestępstw, realizowane poprzez iudicia publica. Za pryncypatu niektóre delikty prywatne objęte zostały również postępowaniem karnym, chociaż same delicta privata nie zanikły, będąc źródłem powstania zobowiązań. W dominacie państwo przejęło ściganie niektórych deliktów prywatnych, pozostawiając niekiedy poszkodowanemu wybór sposobu ścigania. Zob. P. Jörs, W. Kunkel, L. Wenger, Römisches Recht, Berlin, s. 507-508; M. Kaser, K. Hackl, op. cit., s. 2, a także A. Dębiński, J. Misztal-Konecka, M. Wójcik, Prawo rzymskie publiczne, Warszawa 2010, s. 161-203; W. Litewski, Rzymski proces karny, Kraków 2003, s. 15-16; J. Zabłocki, A. Tarwacka, Publiczne prawo rzymskie, Warszawa 2011, s. 116-119 i 174-176; por. M. Kuryłowicz, De publicis iudiciis. Instytucje justyniańskie o postępowaniach sadowych publicznych, [w:] Problemy stosowania prawa sadowego. Ksiegga ofiarowana profesorowi Edwardowi Skrętowiczowi, Lublin 2007, s. 561-572. 
różniło się jednak od współczesnego, oddzielającego prawo materialne od formalnego. Dzisiejsza koncepcja uprawnień podmiotowych, osią której jest posiadanie uprawnienia, zabezpieczone jego zaskarżalnością, nie była znana w prawie rzymskim. Zasadniczo jest ona odwróceniem rozumowania starożytnych Rzymian, polegającym na ujmowaniu realizacji roszczeń od strony procesowej (actio oraz odpowiadająca jej exceptio). Actio miało zatem znaczenie zarówno materialnoprawne, jak i procesowe ${ }^{4}$. Takie podejście było szczególnie widoczne w postępowaniu formułkowym, gdzie actio rozumiana była także jako roszczenie ${ }^{5}$. Dzięki myśleniu skargowemu, bez konieczności wydawania nowych, szczegółowych przepisów prawnych istniała możliwość ukształtowania każdego stosunku prawnego z uwzględnieniem wszystkich okoliczności materialno- i formalnoprawnych.

Rzymskiemu podejściu do prawa procesowego odpowiadała stosowana w tym zakresie terminologia. Nie znano terminu technicznego "proces cywilny" ${ }^{6}$, za reprezentatywne zaś należy w tym zakresie uznać opisowe określenie Gaiusa: ius quod ad actiones pertinet - „prawo, które dotyczy skarg” (G. 1,8). Actiones były powództwami należącymi do iudicia privata, na podstawie których toczyło się postępowanie obejmujące proces legisakcyjny i formułkowy, określane w nauce romanistycznej, jako ordo iudiciorum privatorum ${ }^{7}$. Najstarsza ochrona prawna,

${ }^{4}$ „Actio jest niczym innym, jak prawem sądowego dochodzenia tego, co się komu należy.” (Nihil aliud est actio quam ius quod sibi debeatur, iudicio persequendi. Celsus D. 44,7,51; podobnie I. 4, 6 pr.)

${ }^{5}$ Koncepcja prawa podmiotowego nie była zasadniczo znana prawu rzymskiemu. Actio w procesie kognicyjnym $\mathrm{w}$ większym stopniu miała już charakter ochrony praw podmiotowych, nabierając znaczenia materialnoprawnego. Zob. K. Amielańczyk, Zasada skargowości i zakaz orzekania ponad żadanie stron w procesie rzymskim, „Gdańskie Studia Prawnicze” t. 33, 2015, s. 33-46; R. Jaworska-Stankiewicz, „Qua actione tenetur?” actio a prawo podmiotowe w prawie rzymskim, [w:] Prawa podmiotowe - pojmowanie w naukach prawnych. Zbiór studiów, red. I. Ciapała, K. Flaga-Gieruszyńska, Szczecin 2006, s. 325 nn; W. Dajczak, T. Giaro i F. Longchamps de Bérier, Prawo rzymskie. U podstaw prawa prywatnego, Warszawa 2014, s. 44-45; 154-155; F. Schulz, Classical Roman Law, Oxford 1951, s. 25; E. Szymoszek, Prawo podmiotowe w nauczaniu Stanisława Wróblewskiego, [w:] Honeste vivere. Księga pamiątkowa ku czci Profesora Władysława Bojarskiego, Toruń 2001, s. 257-268; tenże, Uprawnienie-roszczenie-skarga według Stanisława Wróblewskiego, [w:] Valeat aequitas. Księga pamiątkowa ofiarowana Księdzu Profesorowi Remigiuszowi Sobańskiemu, red. M. Pazdan, Katowice 2000, s. 453; R. Wojciechowski, Uwagi o pojęciu „actio” i jego interpretacji, [w:] W kręgu dziejów wymiaru sprawiedliwości, Wrocław 2000, s. 7-16.

${ }^{6}$ Rzymski proces cywilny nie doczekał się również opracowania swej definicji w polskich słownikach i leksykonach, także przedmiotowych. Zob. A. Berger, Enciclopedic Dictionary of Roman Law, Philadelphia 1953; Leksykon tradycji rzymskiego prawa prywatnego. Podstawowe pojęcia. Warszawa 2016; W. Litewski, Słownik encyklopedyczny prawa rzymskiego, Kraków 1998; Prawo rzymskie. Słownik encyklopedyczny, red. W. Wołodkiewicz, Warszawa 1986, gdzie hasła processus brak w ogóle. Autorzy, podając tłumaczenie terminu „processus civilis” jako „proces cywilny”, uznając zapewne oczywistość tego pojęcia, nie podają szerszego wyjaśnienia. Zob. M. Kuryłowicz, Słownik terminów, zwrotów i sentencji prawniczych łacińskich oraz pochodzenia łacińskiego, Warszawa 2012, s. 80; J. Sondel, Słownik łacińsko-polski dla prawników i historyków, Kraków 1997, s. 789.

${ }^{7} \mathrm{~W}$ nauce romanistycznej przeciwstawiane ordo iudiciorum publicorum - zwyczajnemu procesowi karnemu o charakterze publicznoprawnym. Zob. W. Litewski, Słownik..., s. 189; Prawo 
opisywana przez Gaiusa (G. 4, 11-30), udzielana była przy pomocy legis actio i od tego sformułowania określana jako lege agere 8 . Jak z perspektywy dwóch wieków pisał o nich autor „Instytucji” - legis actiones jako restrykcyjne (użycie certa verba), sztywne i sformalizowane, zostały stopniowo znienawidzone i sukcesywnie zastępowane przez nowy typ postępowania sądowego. Agere per legis actiones usunęły zasadniczo leges Juliae iudiciariae z 17 r. przed Chr. Cechujące się większą elastycznością procesowanie się przy użyciu formułek procesowych - agere per formulas, dopuszczone przez lex Aebutia w II w. przed Chr., początkowo alternatywnie w stosunku do postępowania legisakcyjnego, określano także jako agere per concepta verba. Obydwie formy procesu zwyczajnego - legisakcyjny i formułkowy charakteryzowały się dwufazowością, która w ostatnim w rozwoju historycznym typie procesu - kognicyjnym, pierwotnie nadzwyczajnym, została zastąpiona przez ujednolicone, jednofazowe postępowanie przed sędzią państwowym9.

Ustalenie i urzeczywistnienie spornych praw podmiotowych w prawie rzymskim mogło nastąpić na drodze postępowania sądowego, ale również i poza nim. Niektórzy autorzy uważają zatem, że w szerszym ujęciu terminem „proces” należy objąć także czynności postępowania niespornego (nieprocesowego) ${ }^{10}$. Nie budzi raczej wątpliwości fakt, iż z tego pojęcia należy natomiast wyodrębnić pierwotny sposób dochodzenia praw prywatnych, bez udziału sądów, poprzez samopomoc i obronę konieczną. W. Litewski słusznie podnosi, że „o procesie możemy mówić dopiero wtedy, gdy istniała nadrzędna nad stronami władza sądowa, rozstrzygająca o prawidłowości czynności procesowych stron oraz

rzymskie. Słownik..., s. 111; J. Sondel, Słownik..., s. 698.

${ }^{8}$ Zob. P. Jörs, W. Kunkel, L. Wenger, op. cit., s. 508; K. Kolańczyk, Prawo rzymskie..., s. 105 i 113.

9 Cognitio extra ordinem stała się postępowaniem zwyczajnym w 342 r. dzięki konstytucji Konstancjusza II i Konstansa. Historyczną ewolucję i szerszą analizę poszczególnych form procesu cywilnego zawierają dwie, jedyne w języku polskim monografie dotyczące rzymskiego postępowania cywilnego: XIX-wieczny Wykład postępowania cywilnego rzymskiego w zarysie historycznym Dra Walentego Miklaszewskiego, Warszawa 1885 oraz, wydana o wiek później praca W. Litewskiego, Rzymski proces cywilny, Kraków 1988. Z ważniejszych kompleksowych opracowań w tym zakresie należy wskazać: M. Kaser, K. Hackl, op. cit.; L. Wenger, Institutes of the Roman Law of Civil Procedure, New York 1940.; recenzja z tej pracy: H. J. Wolff (rec.), Institutes of the Roman Law of Civil Procedure. Revised Edition, by Leopold Wenger, translated by Otis Harison Fisk, with an introduction by Roscoe Pound. Veritas Press, New York, 1940. PpXXX, 440. \$ 6.00, „Louisiana Law Review”, vol. 5, $\mathrm{nr} 2,1943$, jest dostępna również online: http://digitalcommons.law.lsu.edu/cgi/viewcontent.cgi?a rticle $=1374 \&$ context=lalrev. O postępowaniu kognicyjnym zob. W. Litewski, Studia nad rzymskim postępowaniem kognicyjnym, Kraków 1971. Obszerne wskazówki bibliograficzne dotyczące rzymskiego procesu cywilnego i poszczególnych jego instytucji podaje E. Betti, Processo civile (Diritto Romano), [w:] Novissimo Digesto Italiano, a cura di A. Azara, E. Eula, vol. XIII, Torino 1966, s. 1099-1120, z literatury polskiej należy wskazać tu pozycję M. Zabłockiej, Romanistyka polska po II wojnie światowej, Warszawa 2002, s. 63-72; taż, Romanistyka polska w pierwszym dziesięcioleciu XXI wieku, Warszawa 2013, s. 34-37.

${ }^{10}$ A. Dębiński Rzymskie prawo prywatne. Kompendium, wyd. 5. Warszawa 2011, s. 91. 
sama dokonująca własne akty procesowe"11. Autorzy podejmujący kompleksowo tematykę rzymskiego postępowania cywilnego, zwłaszcza w ujęciu podręcznikowym, uwzględniają $\mathrm{w}$ niej najczęściej także środki ochrony pozaprocesowej, nawet jeśli tytułują część poświęconą tej problematyce „proces cywilny”12.

Nie sposób przy tej okazji pominąć znaczenia pojęcia ,jurysdykcja" (iurisdictio) związanego z działalnością magistratury rzymskiej. Termin ten oznaczał ustne oświadczenie, co jest prawem w konkretnej sprawie i obejmował swoim zakresem zarówno jurysdykcję procesową (iurisdictio contentiosa), jak i nieprocesową (iurisdictio voluntaria) ${ }^{13}$.

Najszerszym pojęciem w zakresie omawianej terminologii wydaje się „ochrona praw podmiotowych”, czy też „ochrona praw prywatnych”. Takie podejście prezentowane było w pewnym stopniu w podręcznikach bazujących na systematyce pandektowej ${ }^{14}$, można je zaobserwować również w podręcznikach współczesnych ${ }^{15}$. Z racji jednak na zasadniczo przeważający w tym zakresie termin „proces cywilny", którym najczęściej posługują się autorzy opracowujący tę tematykę, na potrzeby prezentowanej pracy posłużono się tym właśnie pojęciem.

${ }^{11}$ W. Litewski, Rzymski proces cywilny, s. 10; podobnie M. Kaser, K. Hackl, op. cit., s. 1.

12 A. Dębiński Rzymskie prawo prywatne, s. 128-130; M. Kaser, K. Hackl, op. cit., s. 1-7; K. Kolańczyk, Prawo rzymskie, Warszawa 2005, s. 158-163; M. Kuryłowicz, A. Wiliński, Rzymskie prawo prywatne. Zarys wykładu, wyd. 5, Warszawa 2013, s. 95-97; W. Rozwadowski, Prawo rzymskie. Zarys wykładu wraz z wyborem źródeł, Poznań 1991, s. 72-73;

${ }^{13}$ Współczesna koncepcja jurysdykcji w procesie cywilnym obejmuje kompetencje i uprawnienie właściwego organu do rozstrzygania spraw cywilnych, wynikające z przepisów prawa lub woli stron. W starożytnym państwie rzymskim zakres tego pojęcia miał inny charakter - udzielanie ochrony prawnej w procesie legisakcyjnym i formułkowym nie łączyło się z kompetencją do rozstrzygania sporów prywatnoprawnych, taki wymiar miała natomiast jurysdykcja w rzymskim procesie karnym. Szerzej zob. E. Szymoszek, Iurisdictio w prawie rzymskim. Uwagi o pogląach współczesnych romanistów, „Acta Universitatis Wratislaviensis” 138, Prawo 34 (1971), s. 95-116, a także: W. Litewski, Rzymski proces cywilny, s. 17-18; 35-36; 80-81; B. Miklaszewski, op. cit., s. 10; M. Kaser, K. Hackl, op. cit., s. 183-189; L. Wenger, op. cit. , s. 31-59.

${ }^{14}$ Szerzej zob. niżej, przyp. 63.

15 W. Dajczak, T. Giaro i F. Longchamps de Bérier, op. cit., s. 146-183; W. Wołodkiewicz, M. Zabłocka, Prawo rzymskie. Instytucje, Warszawa 2014, s.275-319. Za autora, dzięki któremu w polskiej literaturze romanistycznej została przyswojona terminologia „ochrony praw prywatnych”, obejmująca nie tylko ochronę w drodze procesu, ale i poza nim, uznaje się Edwarda Gintowta. Za wspólną właściwość „urządzeń prawa prywatnego” przyjmuje on ochronę uprawnionego, urzeczywistniającą się w postępowaniu prowadzonym w celu udzielenia tejże ochrony. W ślad za tym rozumowaniem dzieli swoje opracowanie na cztery rozdziały: I. Prawa prywatne i ich ochrona, II. Formy ochrony praw prywatnych i podział rzymskiego prawa prywatnego, III. Stosunki chronione actione in rem, IV. Stosunki chronione actione in personam. Zob. E. Gintowt, Rzymskie prawo prywatne $w$ epoce postepowania legisakcyjnego, Warszawa 1960 (wydanie wznowione 2005), s. 5-12; zob. także W. Wołodkiewicz, M. Zabłocka, Prawo rzymskie, s. 276. 


\section{Proces cywilny w rzymskim systemie prawnym i systematyce prawa}

Porządek prawa procesowego opierał się na tych samych warstwach prawa rzymskiego, co prawo prywatne (ius civile, ius gentium, ius honorarium) i podlegał analogicznemu, co one rozwojowi ${ }^{16}$. Wpływ na tę ewolucję miały także przemiany ustrojowe państwa rzymskiego, przy czym w większym zakresie było to oddziaływanie w zakresie prawa procesowego, niż prawa określanego dziś jako materialne ${ }^{17}$.

Rzymski proces cywilny nie został nigdy w pełni skodyfikowany, nawet w justyniańskim Corpus Iuris Civilis. Najstarszy pomnik prawa rzymskiego Ustawa XII Tablic ${ }^{18}$, którego systematyka miała charakter asocjacyjny, zawierał tablice I-III, dotyczące norm procesowych. Umieszczenie ich na początku świadczyło niewątpliwie o randze procedury cywilnej ${ }^{19}$. Poza tą regulacją ustawodawstwo ingerowało w ten porządek niezbyt często i niewyczerpująco, największą zaś rolę w ewolucji tego porządku prawnego odegrała praktyka zwyczajowa z udziałem jurysprudencji oraz działalność jurysdykcyjna pretora ${ }^{20}$. Dzięki prawu pretorskiemu, będącemu „żywym głosem prawa cywilnego” - viva vox iuris civilis, rzymskie prawo prywatne rozwijało się, przybierając kształt nadawany mu przez magistratury ${ }^{21}$. Pretor nie mógł, co prawda, bezpośrednio zmieniać ius civile poprzez samo przyznanie bądź odmowę skargi nawet

${ }_{16}$ M. Kaser, K. Hackl, op. cit., s. 3.

${ }^{17}$ M. Kaser, K. Hackl, tamże. Na kierunki ewolucji procesu miały wpływ różnorodne prawotwórcze czynniki rozwojowe: umysłowe, kulturalne, polityczne, gospodarcze i społeczne. Rolę tych ostatnich podkreślał M. Bartošek, wskazując przemiany o charakterze „klasowym”, jakimi były starcia pomiędzy patrycjuszami i plebejuszami. Przyniosły one co prawda zwycięstwo plebejuszom w postaci uchwalenia Ustawy XII Tablic, ale praktyka społeczna stosowania prawa przynosiła zróżnicowanie w pozycji stron procesowych. Zob. M. Bartošek, Třidni základy řimského procesního práva, „Právněhistorické Studie” 14, Praha 1969, s. 131-132 oraz niżej, przyp. 32. Wykształcenie przez proces rzymski szeregu rozwiązań, które miały sprostać zmieniającym się warunkom sygnalizuje także W. Litewski. Zob. tenże, Rzymski proces cywilny, s. 115-116.

${ }_{18}$ M. Zabłocka, J. Zabłocki, Ustawa XII Tablic: tekst, tłumaczenie, objaśnienia, Warszawa 2000; W. Wołodkiewicz, M. Zabłocka, Prawo rzymskie, s. 26-27.

19 Warte odnotowania jest spostrzeżenie E. Gintowta: „Z tego już wynika, że ochrona praw prywatnych miała wówczas dominujące znaczenie, w prawie więc procesowym można się też spodziewać znalezienia punktów oparcia dla wykrycia podziałów prawa prywatnego". Zob. E. Gintowt., op. cit., s. 9.

${ }^{20}$ Szerszymi regulacjami ustawowymi został objęty proces kognicyjny, którego genezy należy szukać w prawie cesarskim. Zob. W. Litewski, Rzymski proces cywilny, s. 11-13; M. Kaser, K. Hackl, op. cit., s. 435-451.

${ }^{21}$ K. Amielańczyk, U podstaw prawa prywatnego. „Rzymski proces cywilny” i jego zasady (uwagi na marginesie nowego podręcznika prawa rzymskiego W. Dajczaka, T. Giaro i F. Longchampsa de Bérier), „Gdańskie Studia Prawnicze”, T. 34, 2010, s. 161; F. Metzger, An Outline of Roman Civil Procedure, „Roman Legal Tradition” vol. 9 (2013), s. 22-23. 
wbrew jego normom, ale miał możliwość udzielenia skargi również w sytuacji, w której prawo nie przewidywało ochrony. Zadania określone jako adiuvare (wspomaganie), supplere (uzupełnianie) i w końcu corrigere (poprawianie) zostały wskazane dopiero na początku III w. przez Papiniana, a zatem z pewnej perspektywy historycznej ${ }^{22}$.

Główne wartości rzymskiego prawa procesowego ukształtowały się w okresie klasycznym, dzięki pracy jurystów i konsyliów pretorskich. Proces formułkowy stawiał im wysokie wymagania umysłowe i obyczajowe, zwłaszcza w zakresie sprawiedliwości i celowości działania, a także nakładając wiele obowiązków. Prawo procesowe stanowiło ius vigilantibus scriptum, które wymagało od stron uwagi i czujności, o ile nie chciały ponieść szkody ${ }^{23}$. Juryści klasyczni nadali procesowi formułkowemu w dalszym rozwoju kunsztowny kształt, dzięki któremu prawo prywatne znajdowało swoje pełne zastosowanie w codziennej praktyce $^{24}$. Szczególne miejsce w zakresie działalności jurysdykcyjnej pretora należy natomiast przypisać edyktowi, zawierającemu przede wszystkim listę actiones i exceptiones, dostępnych dla obywateli rzymskich i będącemu swoistym „prawem postępowania cywilnego". Jego treścią były przede wszystkim deklaracje magistratury co do zakresu ochrony praw prywatnych w procesie i poza nim, co umacniało myślenie skargowe. Układ edyktu korespondował z przebiegiem procesu cywilnego, był bowiem spowodowany jego znaczeniem praktycznym ${ }^{25}$.

„Edykt wieczysty” składał się z pięciu części. Pierwsza obejmowała proces $\mathrm{w}$ fazie in iure, druga - procesowe środki prawne służące do dochodzenia praw prywatnych, trzecia - postępowania szczególne, czwarta - kwestię egzekucji

${ }^{22}$ O prawie pretorskim zob. m.in.: W. Dajczak, T. Giaro i F. Longchamps de Bérier, op. cit., s. 57-58; 154-156; M. Kuryłowicz, Prawo rzymskie. Historia-Tradycja-wspótczesność, Lublin 2013, s. 42-43;

${ }^{23}$ M. Kaser, K. Hackl, op. cit., s. 7: Termin słuszność (aequitas) który stosuje już pretor i którą zaleca sędziom przy sędziowskiej ocenie, nie jest pojęciem bezkształtnym, lecz jest dobrze określone przemyślanymi zasadami, stosowanymi w zależności od rodzaju skargi lub excepcji. Zob. M. Kuryłowicz, Wokół pojęcia „aequitas” w prawie rzymskim, „Studia Iuridica Lublinensia” 15, 2011, s. 15-27.

${ }^{24}$ M. Kaser, K. Hackl, op. cit., s. 5. Warto w tym miejscu dodać, że przede wszystkim właśnie z okresu klasycznego pochodzi ukształtowanie zasad procesowych, uwidocznionych także we współczesnych porządkach procesowych. Zob. szerzej K. Amielańczyk, Zasada skargowości...., s. 33-40; E. Metzger, Roman Judges, Case Law and Principles of Procedure, Roman Law Resources (www. IusCivile.com), s. 19-35; P. Pogonowski, Znaczenie paremii rzymskich dla współczesnej procedury cywilnej, [w:] Starożytne kodyfikacje prawa, red. A. Dębiński, Lublin 2000, s. 187-198.

${ }^{25}$ K. Amielańczyk, U podstaw prawa prywatnego..., s. 161; W. Dajczak, T. Giaro i F. Longchamps de Bérier, op. cit., s. 57-58. Po ujednoliceniu przez Juliana na polecenie cesarza Hadriana „edykt wieczysty" (edictum perpetuum, Edictum Salvianum) mógł być zmieniany i uzupełniany już jedynie przez cesarzy. Rekonstrukcji tekstu edyktu dokonał w XIX wieku O. Lenel, Das Edictum perpetuum: ein Versuch zu seiner Wiederherstellung, Leipzig 1883. Tematyką „edyktu wieczystego”, przy okazji przedstawienia działalności prawodawczej cesarza Hadriana zajął się także T. Dydyński. Zob. tenże, Cesarz Hadrian - studium historyczno-prawne, Warszawa 1889. 
i nieważności wyroku, piąta zaś zawierała formuły interdyktów, ekscepcji, stypulacji pretorskich. Systematyka ta, mimo swej podstawowej funkcji praktycystycznej i małej przejrzystości, odgrywała największe znaczenie w starożytnym Rzymie. Wpłynęła bowiem na dzieła prawników rzymskich, na układ cesarskich zbiorów prawa rzymskiego, przede wszystkim Digestów i Kodeksu justyniańskiego, poza tym nie miała jednak wpływu na późniejszą naukę prawa ${ }^{26}$.

Wyraźne wyodrębnienie prawa dotyczącego powództw w antycznym państwie rzymskim zostało dokonane jedynie przez Gaiusa w „Instytucjach” jako ius quod ad actiones pertinet i stanowiło novum, będąc rozumowaniem oddalonym od, właściwego dla jurystów rzymskich, sposobu patrzenia na prawo materialne i formalne jako na jedność ${ }^{7}$. Trójdzielna systematyka Gaiusa: personae-res-actiones, przejęta przez Instytucje Justyniana ${ }^{28}$, wpłynęła także na podręczniki wydawane od XVI w., przyjmowana była także w okresie I Rzeczypospolitej i kodyfikacjach do czasu systematyki pandektowej ${ }^{29}$.

Zmiany wprowadzone przez pandektystów do trójpodziału Gaiusa polegały między innymi na braku wyodrębnienia $\mathrm{w}$ prawie rzymskim prywatnym prawa procesowego. W systemie pandektowym wydzielono „część ogólną prawa cywilnego", obejmującą podmioty prawa, rzeczy jako przedmioty prawa oraz czynności prawne. Prawo procesowe zostało odseparowane od pozostałych działów prawa tworzących prawo materialne, stając się prawem formalnym i będącym przedmiotem odrębnych kodyfikacji. Systematyka pandektowa miała najszersze, w stosunku do poprzednich klasyfikacji, zastosowanie w opracowywaniu układów nowoczesnych kodeksów cywilnych oraz późniejszej literaturze romanistycznej ${ }^{30}$.

${ }_{26}$ Zob. G. Jędrejek, Prawo rzymskie a systematyka prawa prywatnego w Polsce w XIX-XX wieku, [w:] Starożytne kodyfikacje prawa, red. A. Dębiński, Lublin 2000, s. 211-212; W. Wołodkiewicz, M. Zabłocka, op. cit., s. 28;

${ }^{27}$ Warto dodać, że teza o oryginalnym autorstwie systematyki zastosowanej przez Gaiusa $\mathrm{w}$ „Instytucjach” nie jest ugruntowana w nauce romanistycznej. Koncepcja ta mogła zostać zaczerpnięta z wcześniejszych podręczników do nauki prawa rzymskiego. Por. W. Wołodkiewicz [rec.], Gaio nel suo tempo. Atti del Simposio romanistico, Biblioteca di Labeo, III, Napoli „Jovene 1966, s. VII+161, „Czasopismo Prawno-Historyczne” 21, 1969, z. 1, s. 208-209. O działalności dydaktycznej jurystów rzymskich zob. W. Dajczak, T. Giaro i F. Longchamps de Bérier, op. cit., s. 68-75; T. Dydyński, Historya źródeł prawa rzymskiego, skreślił Teodor Dydyński, Warszawa 1904, s. 163-287; J. Kodrębski, Sabinianie i Prokulianie. Szkoły prawa w Rzymie wczesnego cesarstwa, Łódź 1974; K. Kolańczyk, Prawo rzymskie..., op. cit., s., 28 i 53; W. Litewski, Jurysprudencja rzymska, Kraków 2000, s. 65; W. Rozwadowski, Nauczanie prawa w państwie rzymskim, „Czasopismo Prawno-Historyczne” 55, 2003, z. 1, s. 9-28.

${ }^{28}$ Jak zauważa E. Gintowt: „Mimo zamiłowania do systemizacji, abstrakcji, teoretyzowania, definiowania (...) znamionującego epokę późnego Cesarstwa rzymsko-bizantyjskiego nie doszło w tych czasach do wytworzenia się nowego systemu.” Zob. E. Gintowt, op. cit., s. 145-146.

${ }^{29}$ Zob. G. Jędrejek, op. cit., s. 212-213; W. Wołodkiewicz, M. Zabłocka, op. cit., s. 29-31.

${ }^{30}$ Podstawy pandektystyki (usus modernus pandectarum), czyli kierunku badań obejmujący tzw. współczesne prawo rzymskie, stworzyła XIX-wieczna niemiecka szkoła historyczna. Prawo 


\section{Publiczny czy prywatny charakter rzymskiego procesu cywilnego?}

Kwestia pozycji prawa procesowego cywilnego w systematyce prawa rzymskiego może stać się przedmiotem kontrowersji, gdy spytamy o usytuowanie rzymskiego procesu cywilnego w podziale prawa na ius publicum i ius privatum.

Pozostawiając obszerne dyskusje i liczne teorie związane z tą dychotomią ${ }^{31}$, trzeba jednak zaznaczyć, że mogą one mieć wpływ na zasady kwalifikowania określonych norm do sfery prawa publicznego bądź prywatnego, różnicując je w zależności od kryterium podziału. Co do zasady należy uznać, że główny cel rzymskiego procesu cywilnego, poza przesłanką natury ogólnej, jaką było zapewnienie ładu prawnego i porządku publicznego, stanowiła ochrona interesów prywatnych jednostek. Organy państwa miały za zadanie pomóc podmiotowi posiadającemu określone uprawnienia w ich zabezpieczeniu. Wystąpienie o tę pomoc zależało od woli jednostki, państwo nie wkraczało w tę sferę działaniami „Z urzędu”, nie miała ona zatem charakteru publicznoprawnego ${ }^{32}$.

Należy zauważyć, że w rzymskim prawie procesowym rozwinęła się zasada podziału funkcji między organem państwowym (element publiczny) i sędziami

pandektowe było wykładane w uniwersytetach niemieckich jako pozytywne prawo prywatne i obowiązywało w Niemczech aż do wejścia w życie w 1900 roku Bürgerliches Gesetzbuch - ogólnoniemieckiego kodeksu cywilnego. Poglądy pandektystów (m.in. B. Windscheida, autora znanego Lehrbuch des Pandektenrechts, Düsseldorf 1862-70) wywarły duży wpływ na naukę prawa w całej Europie. Na temat szkoły historycznej, pandektystyki i jej wpływu na naukę prawa zob. m.in.: G. Jędrejek, Powstanie, rozwój i znaczenie niemieckiej szkoły historyczno-prawnej, „Summarium” 32 (52) 2003, s. 130-158; H. Kupiszewski, Prawo rzymskie a współczesność, Warszawa 1988, s. 80-90; M. Kuryłowicz, Prawo rzymskie..., s. 103-104; R. Wojciechowski, O pojęciu pandektystyki, „Acta Uniwersitatis Wratislaviensis", Prawo 290, 2004, s. 25-38; tenże, Bernhard Windscheid (1817-1892), „Kwartalnik Prawa Prywatnego” 18, 2009, s. 593-620.

${ }^{31}$ Sama treść i zakres rzymskiego prawa publicznego może być przedmiotem dyskusji. Słynne ujęcie Ulpiana: Publicum ius est quod ad statum rei Romanae spectat, ius privatum est quod ad singulorum utilitatem: sunt enim quaedam publice utilia, qauedam privatim (D. 1, 1, 1, 2; I. 1,1,4) stało się źródłem różnych i wielowątkowych interpretacji. Samo kryterium rozróżnienia, zdaniem jednych autorów, stanowiła w tej definicji utilitas (interes, korzyść) - państwa, bądź jednostek (G. Dulckeit, K. Kolańczyk), inni zaś, przy analizie tego rozgraniczenia wskazują „przedmiot” owej regulacji (np. T. Mommsen - prawem publicznym są przepisy odnoszące się do wspólnoty, a prywatnym - odnoszące się do poszczególnych jednostek). Według innego wnioskowania, kryterium decydującym o wyróżnieniu norm prawa publicznego jest ich pochodzenie (H. Müllejans, M. Kaser). Szerzej (wraz z obszerną literaturą) zob. J. Nowacki, Prawo publiczne-prawo prywatne, Katowice 1992, s. 8-32.

${ }^{32}$ Generalnie, choć nie bezwarunkowo, przyjmuje się, że sprawy rozstrzygane w drodze postępowania cywilnego $\mathrm{w}$ zasadzie pokrywają się z dziedziną prawa prywatnego, natomiast sprawy publicznoprawne są przedmiotem innych postępowań (administracyjnego, karnego). Szerzej na ten temat zob. tamże, s. 34-36. Na temat publicznych elementów występujących w niektórych skargach rzymskiego procesu cywilnego zob. W. Mossakowski, Elementy cywilnoprawne rzymskich skarg cywilnych, [w:] Honeste vivere..., s. 133-138. 
(element prywatny), na których wybór miały strony. Była ona wyraźna zwłaszcza w czasach rozkwitu pryncypatu, uznawano ją za wyraz rzymskiej kultury oraz demokratycznej postawy państwa. Stanowiła także przejaw rzymskiego przekonania, iż ten system zapewnia należytą ochronę prawną ${ }^{33}$.

Występowanie w rzymskim procesie cywilnym elementów publicznych i prywatnych oraz konieczność współdziałania pomiędzy nimi uwidocznione są w sposób szczególny w procesie formułkowym. Był on prowadzony w dwóch fazach, w każdej z nich można zaobserwować przeplatanie się czynników o charakterze publicznym i prywatnym.

Pozwanie do sądu (in ius vocatio) wymagało inicjatywy powoda, miało więc charakter prywatny. Choć było dokonywane nieformalnie, jego skutkiem był obowiązek stawiennictwa przed magistraturą, reprezentującą państwo ${ }^{34}$.

Czynnik publiczny jest zauważalny przede wszystkim w pierwszej fazie procesu (in iure), w której podstawową rolę odgrywały rzymskie magistratury, przed którymi się toczyło postępowanie. Należy tu podkreślić szczególną rangę pretora - „pana procesu”, którego funkcja prawotwórcza umożliwiała właściwy rozwój dalszego postępowania. Bez jego decyzji postępowanie nie przechodziło do sędziego, bez jego upoważnienia sędzia nie mógł wydać wyroku uznanego

${ }^{33}$ M. Kaser, K. Hackl, op. cit., s. 8. Nie była to jednak należyta ochrona, jak wiemy z ustaleń badaczy prawa rzymskiego i historyków. Teoria M. Wlassaka o „demokratyczności” procesu została zdecydowanie odrzucona jako anachroniczna iluzja ostatecznie w latach sześćdziesiątych XX wieku. Ingerencja magistratury w stosunki prywatne w procesie w zasadzie była niewielka. Pozycja stron nosiła zaś cechy nierównorzędności ze względu na występujące pomiędzy nimi różnice społeczne i ekonomiczne. Tę kwestię jako pierwszy podniósł R. Jhering, wskazując na niewielkie szanse biednego proletariusza w procesie przeciw posiadaczowi ziemskiemu. Społeczną rzeczywistość rzymskiej ochrony prawnej badał J. M. Kelly, zaś J. A. Crook poszerzał tę problematykę od strony socjologicznej. Zob. J. Crook, Law and Life of Rome, London 1967; J. M. Kelly, Roman Litigation, Oxford 1966; tenże, Studies in the Civil Judicature of the Roman Republic, Oxford 1976, s. 71-93. K. Kolańczyk za G.I. Luzzato stwierdzał, że zarówno w Rzymie, jak i dzisiaj, mechanizmy procesowe są nastawione na ochronę określonego statusu społeczno-ekonomicznego znaczących grup społecznych. Zob. K. Kolańczyk, Über den Bildungswert ..., s. 280-285. Obszernie na temat iluzji równości obywateli zakładanej przez prawo materialne, a mającej odnaleźć realizację w prawie procesowym pisał M. Bartošek: „Bogaty patrycjusz mógł zmusić plebejusza do posłuszeństwa, czego nie mógł praktycznie zrobić plebejusz wobec patrycjusza. A zatem: przepis jest jasny i prosty, a w praktyce zastosowanie jego było czysto jednostronne. (...) wniosek jest jeden i prosty: klasowe społeczeństwo, opanowane przez garstkę bogaczy kosztem milionów biedaków, i klasowe prawo, które utrwalało taki stan rzeczy." M. Bartošek postulował przy tym szczegółowe badania w tym zakresie, które powinny prowadzić do właściwego zrozumienia rzymskiego prawa procesowego. Zob. tenże, Třidni základy ..., s. 117-163. Przeglądu badań na temat wpływu pochodzenia społecznego jurysprudencji rzymskiej na pozycję poszczególnych prawników i ich oceny, przede wszystkim z punktu widzenia potrzeb romanistyki marksistowskiej dokonał natomiast K. Kolańczyk w artykule O pochodzeniu i stanowisku społecznym jurystów rzymskich, „Czasopismo Prawno-Historyczne” 1955, t. 7, z. 1, s. 227-284.

${ }^{34}$ P. Jörs, W. Kunkel, L. Wenger, op. cit., s. 527; M. Kaser, K. Hackl, op. cit., s. 64-66, 93; W. Litewski, Rzymski proces cywilny, s. 22, 43 i 109; W. Miklaszewski, op. cit, s. 142-147. 
przez państwo za wiążący ${ }^{35}$. Pretor dysponował formułkami skarg, mógł ich udzielić bądź odmówić ich udzielenia, nadzorował działania stron, miał również możliwość odesłania ich w celu ustalenia pomiędzy nimi treści sporu i stosownej formułki skargi ${ }^{36}$. Jeżeli pretor udzielił skargi, następny krok należał do pozwanego, który mógł roszczenie uznać, zaprzeczyć mu, bądź też pozostać bierny. $\mathrm{Na}$ dalsze losy procesu miał w tym miejscu zatem wpływ czynnik prywatny ${ }^{37}$.

Do elementów prywatnych procesu rzymskiego należy, co do zasady, zaliczyć również pomoc prawników rzymskich, udzielaną stronom $w$ toku postępowania zarówno przez adwokatów (advocati) ${ }^{38}$ oraz retorów (oratores, perorationes), występujących w drugiej fazie procesu ${ }^{39}$. Należy odróżnić od niej działalność iuris periti (iuris consulti, iurisprudentes) ${ }^{40}$, która mogła mieć charakter uznany przez za wiążący (responsa prudentium), jeśli posiadali oni nadane przez cesarza

${ }^{35}$ P. Jörs, W. Kunkel, L. Wenger, op. cit., s. 510; M. Kaser, K. Hackl, s. 8. Pretor nie mógł jednak sam doprowadzić postępowania do końca, sprawa mogła się zakończyć u niego jedynie wtedy, gdy przestała być sporna. Zob. E. Gintowt, op. cit., s. 10.

${ }^{36}$ M. Kuryłowicz (rec.), Alfons Bürge, Römisches Privatrecht: Rechtsdenken und gesellschaftliche Verankerung; eine Einführung, Wissenschaftliche Buchgesellschaft, Darmstadt 1999, stron XII, 248, indeksy, „Czasopismo Prawno-Historyczne“ (52) 2000, z. 2., s. 362.

${ }^{37}$ M. Kaser, K. Hackl, op. cit., s. 172-183; W. Litewski, Rzymski proces cywilny, s. 46-49; W. Miklaszewski, op. cit, s. 116-138 i 154-155.

${ }^{38}$ Advocati, causidici, scholastici, togati występowali jako pomocnicy stron. Ich rola wyglądała podobnie w postępowaniu formułkowym i kognicyjnym. Cieszyli się prestiżem społecznym, posiadając wykształcenie prawnicze. Za dominatu adwokatura została zorganizowana w przymusowe korporacje. W tym czasie zawód adwokata zaczął być określany jako militia - służba na rzecz państwa, uznana za taką przez cesarza Leona w 496 r. Wówczas adwokaci zaczęli coraz częściej występować jako pełnomocnicy procesowi stron. Zob. A. Berger, op. cit., s. 352; W. Litewski, Rzymski proces cywilny, s. 83; M. Jonaitis, I. Žalèniené, The concept of bar and fundamental principles of an advocate's acitivity in Roman Law, „Jurisprudence” 2009, 3 (117), s. 299-312; dostępne online: https://www. mruni.eu/upload/iblock/6db/jonaitis_zaleniene.pdf.; R. Łyczywek, Marek T. Cyceron - adwokat rzymski, „Palestra” 4/9 (33) 1960, s. 75-91; B. Miklaszewski, op. cit., s. 172-177. Zob. także artykuł o charakterze popularnonaukowym: M. Jońca, Pojawienie się kobiet $w$ adwokaturze a kłopotliwy balast rzymskiego prawa, „Edukacja Prawnicza” 2010, nr 3, s. 27-28.

39 Retorzy, mówcy sądowi, występujący obok stron i ich zastępców, których celem było psychiczne oddziaływanie na sąd, występowali oni w drugiej fazie postępowania. Mieli zasadniczo wykształcenie retoryczne. Perorationes wygłaszali przemowy zawierające argumentacje na korzyść stron. Terminologia dotycząca poszczególne kategorie prawników, pomagających w procesie zaczęła się zlewać w okresie dominatu. Zob. A. Berger, op. cit., s. 611; W. Litewski, Rzymski proces cywilny, s. 22; 42; 60; P. Kubiak, Kilka uwag o znajomości prawa u mówców sądowych republikańskiego Rzymu, „Krakowskie Studia z Historii Państwa i Prawa” 2015, t. 8, z. 1, s. 1-24.

${ }^{40} \mathrm{Na}$ temat prawa jurysprudencyjnego zob. P. Święcicka, Prawo jurysprudencyjne jako prawniczy dyskurs argumentacyjny: (zarys problematyki), „Zeszyty Prawnicze” 11.1 (2011), s. 317-338. O jurystach rzymskich zob. szerzej także T. Dydyński, Historya źródeł, s. 167-283; K. Kolańczyk, O pochodzeniu i stanowisku...; W. Litewski, Jurysprudencja rzymska, Kraków 2000. Por. też ostatnio M. Kuryłowicz, „Eminentissimo viro iuris consulto...” Rzymscy juryści $w$ tekstach epigraficznych, „Studia Iuridica Lublinensia" vol. XXV, 3, 2016, s. 497-509. 
ius respondendi ${ }^{41}$, w pozostałych zaś przypadkach miała charakter opinii prywatnych. Z pomocy prawników rzymskich korzystały zarówno strony, chcące uniknąć błędu na swoją szkodę, jak i pretor przed podjęciem decyzji.

Prawnicy (oratores, patroni) mogli także reprezentować strony w procesie cywilnym. Zastępstwo procesowe, niedopuszczalne w procesie legisakcyjnym, występowało w procesie formułkowym i kognicyjnym, stanowiąc również element prywatny ${ }^{42}$.

Ważny i konieczny dla procesu rzymskiego akt, jakim była litis contestatio, też zasadniczo miał charakter prywatny, wymagającym jednak współudziału stron i pretora ${ }^{43}$. W procesie formułkowym poprzez litis contestatio strony wyrażały wolę przyjęcia wyznaczonego przez magistraturę sędziego (iudex) i pisemną formułkę procesową. Ta zaś, zawierając całość spornych i prawnych kwestii, stanowiących program procesowy i oznaczenie sędziego, była uprzednio ustalana wspólnie przez magistratus i strony ${ }^{44}$.

Czynnik prywatny w drugiej fazie procesu stanowiła osoba i rola sędziego, który współdziałał z pretorem i ze stronami, przez które został wybrany ${ }^{45}$. Sędziami były w procesie formułkowym osoby prywatne, nie zaś funkcjonariusze administracji państwowej, jak to było w postępowaniu kognicyjnym. Osobę sędziego ustalały obie strony, w razie braku porozumienia w tej sprawie,

${ }^{41}$ A. Berger, op. cit., s. 532; K. Kolańczyk, O pochodzeniu i stanowisku..., s. 229; W. Litewski, Jurysprudencja rzymska, s. 45-47.

${ }^{42}$ Cognitor - zastępca ustanowiony formalnie oraz procurator - zastępca ustanowiony nieformalnie. W procesie kognicyjnym procurator stał się jedynym zastępcą procesowym. O zastępstwie procesowym zob. A. Berger, op. cit., s. 394; 653; B. Miklaszewski, op. cit., s. 156-168. W. Rozwadowski, Kognitor jako zastępca w procesie rzymskim, „Gdańskie Studia Prawnicze” 17, 2007, s. 573-582, tenże, Studi sulle 'exceptiones cognitoriae' e 'procuratoriae', Fides, Humanitas, Ius. Studii in onore di Luigi Labruna, VII, Napoli 2007, s. 4801-4817; L. Wenger, Institutes of the Roman Law of Civil Procedure, New York 1955, s. 88-92.

${ }^{43} \mathrm{~W}$ procesach zwyczajnych podstawowym skutkiem litis contestatio była zawisłość sporu, powodująca niedopuszczalność wniesienia kolejnej skargi w tej samej sprawie. Znaczenie litis contestatio było największe w procesie formułkowym, najmniejsze zaś w procesie kognicyjnym, w którym zawisłość sporu powstawała już w chwili pozwania. W każdym z rodzajów rzymskiego procesu cywilnego przy litis contestatio konieczny był udział stron i magistratury. Na temat litis contestatio w poszczególnych typach procesu zob. szerzej: A. Berger, op. cit., s. 566; E. Betti, op. cit., s. 1108-1109; P. Jörs, W. Kunkel, L. Wenger, op. cit., s. 527; H. Kupiszewski, Litis contestatio, „Czasopismo Prawno-Historyczne" 1963, t. 13, z. 1, s. 243-265; W. Litewski, Rzymski proces cywilny, s. 23-24; 49-51; 89-90; tenże, „Litis contestatio” en obligations solidaires passives dans les „bonae fidei iudicia” en droit Romain classique, „Revue Historique de Droit Français et Étranger” 54, 1976 nr 2, s. 149-175; tenże, L'effet libératoire de la "litis contestatio" dans les obligations solidaires actives en droit de Justinien, „Labeo” 24, 1978, s. 301-316; B. Miklaszewski, op. cit., s. 202-228; L. Wenger, op. cit., $177-183$.

${ }^{44}$ Literatura dotycząca formułki procesowej (formula, iudicium, actio), jej rodzajów oraz elementów jest bardzo bogata. Zob. (z dalszymi wskazówkami bibliograficznymi): A. Berger, op. cit., s. 477-475; E. Betti, op. cit., s. 112; F. Schulz, op. cit., s. 21-22; L. Wenger, op. cit., s. 140-175

${ }_{45}$ Por. K. Kolańczyk, Über den Bildungswert..., s. 283 
proponował ją powód aż do akceptacji pozwanego. Ostatecznie, przy braku zgodności, dokonywano losowania. Wybór sędziego był zatwierdzany przez pretora, który umieszczał jego nazwisko na początku formułki procesowej ${ }^{46}$. $\mathrm{Za}$ element publiczny należy uznać nakaz wyrokowania (iudicare iubere) wydany sędziemu przez magistratus. Postępowanie dowodowe zależało jednak przede wszystkim od stron, zaś rola sędziego mogła sprowadzić się w zasadzie do prostego zasądzenia zgodnie z treścią formułki, bądź oddalenia powództwa, zgodnie z rozwiniętą zasadą sędziowskiej oceny dowodów (w formułce: si paret condemnato, si non paret absolvito ${ }^{47}$.

Po wydaniu przez sędziego wyroku, w procesach zwyczajnych będącego prawomocnym jedynie formalnie ${ }^{48}$, następowała egzekucja osobista lub majątkowa. Podmiotem dominującym na tym etapie stawał się powód (wierzyciel), reprezentujący czynnik prywatny, dopuszczalność i skuteczność była jednakże uzależniona od czynnika publicznego, jaki stanowił nadzór magistratury ${ }^{49}$.

${ }^{46}$ Sędzia (iudex) w procesach zwyczajnych otrzymywał publiczną funkcję sędziowską i był wybierany z listy sędziów (album iudiciorum selectorum), która pierwotnie obejmowała tylko stan senatorski, później także ekwitów. Wśród wymogów, jakie musiał spełnić kandydat na sędziego (wiek 30, a potem 25 lat oraz cenzus majątkowy) nie było wykształcenia prawniczego, sędziowie korzystali więc z reguły z pomocy consilium - rady jurystów. Zasadą było rozpatrywanie spraw przez pojedynczego sędziego (iudex unus), ale istniały także sądy kolegialne (centumviri, decemviri, recuperatores). Określenia arbiter używano dla sędziów polubownych, mianowanych przez magistraturę dla rozstrzygnięcia sporu wymagającego specjalnego badania okoliczności faktycznych czy fachowej wiedzy lub z większą swobodą uznania (skargi działowe, bonae fidei iudicia, arbitrium). Swoboda stron przy wyborze sędziego była największa w procesie formułkowym, obejmowała także możliwość wskazania go spoza listy, w procesie legisakcyjnym był on wyznaczany przez magistraturę, uwzględniającą prawdopodobnie wolę stron. Zob. A. Berger, op. cit., s. 365-366; 518-519; P. Jörs, W. Kunkel, L. Wenger, op. cit., s. 510; J. M. Kelly, op. cit., s. 1-70, 112-133; W. Litewski, Rzymski proces cywilny, s. 18-19, 37-38; . W. Miklaszewski, op. cit., s. 14-21; Prawo rzymskie. Słownik..., s. 25 i 78.

${ }^{47}$ Większą autonomię miał w tym zakresie arbiter. W procesie legisakcyjnym dowody oceniano w zasadzie swobodnie, proces formułkowy także nie znał stałych reguł dowodowych, stworzono je dopiero w procesie kognicyjnym, w ograniczonym jednak zakresie. Zob. W. Litewski, Rzymski proces cywilny, s. 111-112; L. Wenger, op. cit., s. 195-205; R. Wojciechowski, Arbiter w prawie rzymskim, [w:] Postępowanie polubowne w dziejach, Wrocław 2006, s. 17-25. O pozycji sędziego wobec stron oraz w toku procesu pisali E. Szymoszek oraz J. Zabłocki. Zob. wskazówki bibliograficzne M. Zabłocka, Romanistyka polska po II wojnie..., s. 68-69.

${ }^{48} \mathrm{~W}$ obydwu typach procesu nie znano zwyczajnych środków zaskarżenia, zatem każdy wyrok był prawomocny formalnie. Apelację dopuszczono w procesie kognicyjnym, powodując zarazem prawomocność materialną wyroków sądowych. Zob. W. Litewski, Wybrane zagadnienia rzymskiej apelacji w sprawach cywilnych, Kraków 1967; S. Stankiewicz, Z badań nad powagą rzeczy osądzonej (res iudicata) w prawie rzymskim. Wybrane problemy badawcze, „Annales Universitatis Mariae Curie-Skłodowska" sectio G, vol. LXI, 2, 2014, s. 115-126; L. Wenger, op. cit., s. 206-221.

${ }^{49} \mathrm{~W}$ procesie kognicyjnym egzekucję przeprowadzał już sąd. Surowe zasady egzekucyjne zdecydowanie faworyzowały bogatszych, dyskryminując osoby uboższe i o słabszej pozycji społecznej, chronionych tylko w nielicznych przypadkach. Zob. J. M. Kelly, s. 71-92. Na temat postępowania egzekucyjnego w rozwoju historycznym rzymskiego procesu cywilnego oraz poszczególnych rodzajach egzekucji oraz dalsze wskazówki bibliograficzne zob. E. Betti, op. cit., s. 1117-1120; 
Rozwój rzymskiego procesu cywilnego, w szczególności przejście do jednofazowego procesu kognicyjnego oznaczało zasadniczą zmianę w podejściu państwa do procesu, zdecydowanie wzmacniającym jego publiczne cechy. Całość postępowania $\mathrm{w}$ sprawach prywatnych przeszła bowiem $\mathrm{w}$ ręce urzędnika państwowego. Sukcesywnie rosła rola sądu, a zatem elementu publicznego ${ }^{50}$.

Powojenna nauka romanistyczna, dotycząca rzymskiego prawa procesowego, przyniosła obfitość publikacji w tym zakresie, w tym także ewolucję poglądów i ustaleń w kwestii charakteru rzymskiego procesu cywilnego ${ }^{51}$. Na ich skutek „sławny „proces prywatny” [Privatprozess] stał się bardziej „spublicyzowany”, niż to wcześniej opisywano" 52 . Podkreślano coraz bardziej rolę magistratury, odchodząc od wcześniejszego założenia, że proces był prowadzony wyłącznie czy w przeważającej mierze na podstawie woli stron pozostających w sporze. Zauważano intensywny wzrost i umacnianie się pozycji pretora w procesie formułkowym, jak również brak całkowitej swobody stron przy ustanawianiu sędziego ${ }^{53}$. Większym zainteresowaniem objęto społeczne i ekonomiczne aspekty rzymskiej ochrony procesowej, co wynikało przede wszystkim z przyczyn natury ideologicznej. Dla „prawnika socjalistycznego” istotne było to, komu i w jaki sposób ta ochrona mogła służyć, postulowano zatem rozwijanie badań nad społecznymi treściami rzymskiego procesu cywilnego ${ }^{54}$. Ten kierunek

W. Litewski, Rzymski proces cywilny, s. 29-32, 64-71, 99-102, 115-116; W. Miklaszewski, op. cit., s. 319-331; I. Szpringer, Wybrane przywileje egzekucyjne w prawie rzymskim, [w:] Quid leges sine moribus? Studia nad prawem rzymskim dedykowane Markowi Kuryłowiczowi w 65. Rocznicę urodzin oraz 40-lecie pracy naukowej, red. A. Amielańczyk, Lublin 2009, s. 125-141; L. Wenger, op. cit., s. 223-240; J. Zabłocki, Postępowanie egzekucyjne w Ustawie XII Tablic, [w:] Czynić sprawiedliwość w miłości. Księga pamiątkowa od Uniwersytetu Kardynała Stefana Wyszyńskiego dla Jego Eminencji Józefa Kardynała Glempa w dwudziestą rocznice posługi Prymasowskiej, Warszawa 2001, s. 310-334; I. Żeber, „Capio pignoris” w prawie rzymskim, s. 23-48, [w:] Postępowanie egzekucyjne w dziejach, Wrocław 2007, s. 23-48.

${ }^{50}$ Postępowanie kognicyjne stanowiło podstawę do dalszego rozwoju procesu, w szczególności rzymsko-kanonicznego w średniowieczu i czasach nowożytnych. Wskazówki bibliograficzne dotyczące procesu rzymsko-kanonicznego zawierają pozycje: E. Betti, op. cit., s. 1120; M. Zabłocka, Romanistyka polska po II wojnie..., s. 68.

${ }^{51}$ Obszerną literaturę na ten temat przytacza K. Kolańczyk: „Z publikacji procesowych ostatnich lat można by zebrać sporą biblioteczkę, w której jednak nawet osobie obeznanej z tematyką ciężko jest się poruszać”. K. Kolańczyk, Über den Bildungswert..., s. 281 i 295-299.

52 Tamże, s. 282

53 Tamże, s. 282-283

${ }^{54} \mathrm{~K}$. Kolańczyk wskazał w tym zakresie konkretne problemy wymagające szczególnego zainteresowania i opracowania. Były to, jego zdaniem: pomoc własna, ordo iudiciorum privatorum (podmioty tworzące go oraz z góry z niego wykluczone), zakres władzy magistratury przy denegatio actionis, prawdopodobny nacisk na polubowne (ugodowe) zakończenie sprawy w rzymskiej praktyce procesowej, zwłaszcza w wykonaniu silniejszej strony (problemy społeczne), ekonomiczne i społeczne skutki ryzyka prowadzenia procesu oraz ponoszenia jego kosztów, społeczna ostrość rzymskiej egzekucji oraz całościowe oszacowanie rzymskiego procesu cywilnego z politycznego, ekonomicznego oraz społecznego punktów widzenia. Tamże, s. 288-289. Podobne, poszerzone jeszcze wskazówki, o charakterze 
badawczy prowadził jej reprezentantów do pogłębionej analizy elementów klasowych w rzymskim prawie procesowym, a także do koncepcji, że rzymski proces cywilny stanowi część całego prawa rzymskiego i nie należy utożsamiać tych norm z prawem publicznym, pozostając pod wpływem współczesnego prawa procesowego $0^{55}$.

Dziś przeważa zdecydowanie pogląd o publicznoprawnym charakterze rzymskiego procesu cywilnego, przy zaznaczeniu istnienia w nim elementów prywatnych $^{56}$. Należy uznać za raczej już utrwaloną analogiczną koncepcję dotyczącą współczesnego postępowania cywilnego, przyznającą, iż u jego podłoża stoi teoria stosunku prawnoprocesowego O. Bülowa, bazująca na prawie rzymskim procesowym ${ }^{57}$.

\section{Miejsce procesu cywilnego w systematyce podręczników prawa rzymskiego}

W poglądach na dydaktykę prawa rzymskiego zgodne jest stanowisko, zgodnie z którym bez dobrego poznania przez przyszłego prawnika rzymskiego procesu nie jest możliwa prawidłowa orientacja w systemie prawa prywatnego starożytnych Rzymian i ich sposobie myślenia o prawie. Pozwala ono ponadto przyszłemu juryście lepiej opanować zagadnienia współczesnego procesu ${ }^{58}$.

zarazem metodologicznym, mające doprowadzić do lepszego poznania miejsca procesu rzymskiego w społecznej rzeczywistości sformułował M. Bartošek, Eksponował przy tym braki w badaniach prowadzonych przez „romanistów burżuazyjnych”, które powinni uzupełnić „romaniści marksistowscy”. Zob. M. Bartošek, Třidni základy ..., s. 126-130.

${ }^{55}$ M. Bartošek krytykował za to podejście romanistykę burżuazyjną, odnoszącą się do rzymskiego prawa procesowego jako prawa formalnego. Podkreślał przy tym, skądinąd słusznie, że prawnicy rzymscy nie przeciwstawiali prawa materialnego prawu formalnemu i widzieli tu raczej jedność, czego wyrazem było pytanie: Qualis actio? „Romanistyka marksistowska stawia kolejne pytania co do dalszych związanych z tym okoliczności: Quid ius? Quia ius? Quo modo ius? Quale ius? Qualis praetor? Qualis iudex?” Wywodził także, iż rzymski proces cywilny w okresie klasycznym stanowił iudicium privatum. M. Bartošek, Třidni základy ..., s. 129.

${ }^{56}$ M. Kaser, K. Hackl, op. cit, s. 8.

${ }^{57}$ Proces cywilny w tym ujęciu jest rozumiany jako stosunek publicznoprawny, rozwijający się stopniowo, w którym zostaje wyjaśniony spór prywatnoprawny. Zob. O. Bülow, Die Lehre von den Processeinreden und die Processvoraussetzungen, Giesen 1968; J. Nowacki, op. cit., s. 34-38; P. Osowy, Powództwa o ukształtowanie stosunku prawnego, Warszawa 2015, s. 20-21; M. G. Plebanek, Nadużycie praw procesowych w postępowaniu cywilnym, Warszawa 2012, s. 26.

${ }^{58}$ Dydaktyczne wartości nauczania procesu rzymskiego podnosił m. in. H. Keller, poparty przez M. Kasera, a później K. Kolańczyka, który określił je jako „kolebkę prawa materialnego”, podkreślając jednocześnie, że obraz procesu, wskutek pogłębionych badań jest bliższy życia i ówczesnej rzeczywistości i taki właśnie obraz należy przekazać studentom. Dzięki temu uświadomią sobie oni również współczesne skutki ochrony prawnej wraz z jej niesprawiedliwościami i nadużyciami. Zob. K. Kolańczyk, Über den Bildungswert..., s. 279-293. Znaczenie historyczne i społeczne nauczania 
Bezdyskusyjna zatem jest celowość wykładu obejmującego w swej treści rzymski proces cywilny ${ }^{59}$. Należy jednak zgodzić się z L. Wengerem, że ta część historii prawa jest niewątpliwie najtrudniejszym jej fragmentem i mieć to na uwadze, zwłaszcza przy realizacji celów dydaktycznych. Proces cywilny jest przedstawiany we współczesnych podręcznikach prawa rzymskiego, nawet jeżeli ich tytuł zapowiada przedstawienie jedynie prawa prywatnego, ilustrując sposób ochrony prawnej w starożytnym Rzymie. Przedmiotem ewentualnych rozważań natury metodologicznej może stać się jedynie jego umiejscowienie oraz zakres.

Najbardziej znanym podręcznikiem prawa rzymskiego powstałym w starożytnym państwie rzymskim stały się „Instytucje” Gaiusa, których autor uznał za celowe umieszczenie ius quod ad actiones pertinet $\mathrm{w}$ ostatniej ich części. Do tego układu nawiązuje współcześnie jedynie podręcznik współautorów W. Wołodkiewicza i M. Zabłocka ${ }^{60}$, stanowiąc w tym zakresie zasadniczo wyjątek. Zdaniem autorów umieszczenie prawa formalnego po zaprezentowaniu części materialnej jest bliższe współczesnemu pojmowaniu roli procesu cywilnego i daje możliwość przybliżenia studentom podobieństw miedzy systemem prawa rzymskiego i współczesnym systemem prawnym.

Również na końcu podręcznika prawo procesowe zostało wcześniej umieszczone jedynie przez W. Litewskiego ${ }^{61}$, nastąpiło to jednak z przyczyn innej natury, a mianowicie „śladem podręczników niemieckich"62.

Poza wskazanymi przykładami jest to podejście raczej odosobnione w powojennej literaturze podręcznikowej prawa rzymskiego ${ }^{63}$. Większość podziału dzisiejszych podręczników prawa rzymskiego oparto zasadniczo na systematyce pandektowej, co jest widoczne zwłaszcza w starszych, przedwojennych syntezach

rzymskiego prawa procesowego w społeczeństwie socjalistycznym podkreślał M. Bartošek. Zob. tenże, Ř́mské právo a socialistická spoločnost, [w:] „Rozpravy Československé Akademie Véd Řada Společenských Věd” 76 (1966), z. 12, Československé Akademie Véd, Praha 1966, s. 5-36. Współcześnie zob. np. K. Amielańczyk, U podstaw prawa prywatnego..., s. 160-175.

${ }^{59}$ K. Kolańczyk, Über den Bildungswert..., s. 279 i 290.

${ }^{60}$ Prawo rzymskie. Instytucje Wyd. 6, Warszawa 2014.

${ }^{61}$ Rzymskie prawo prywatne, Warszawa 1990.

${ }^{62}$ Jak zauważa K. Kolańczyk, Prawo rzymskie, s. 103, przyp. 2, za nim również P. Święcicka w wydawnictwie o charakterze repetytorium: Rzymskie prawo prywatne, Warszawa 2011, s. 383.

${ }^{63}$ Niewątpliwie dotyczy to podręczników, które ukazały się w ostatnich dziesięcioleciach. Zestawienia w tym zakresie, sięgające początku lat sześćdziesiątych XX wieku dokonał K. Kolańczyk, na marginesie recenzji podręcznika W. Osuchowskiego. Wśród podręczników przedstawiających proces cywilny po wykładzie prawa materialnego wymienił dzieła francuskie i angielskie: Girarda, Cuqa, Bucklanda oraz niemieckie: Czyhlarza, Sohma, Jörsa-Kunkela-Wengera, Kasera i polskie Taubenschlaga, w jego czterech pierwszych wydaniach. Zob. Kolańczyk K., (rec.), Nowy podręcznik rzymskiego prawa prywatnego. Uwagi w związku z praca Wacława Osuchowskiego, Zarys rzymskiego prawa prywatnego, Warszawa 1962, PWN, ss. 553, „Czasopismo Prawno-Historyczne” 1965, t. XVII, z. 1, s. 243. 
o celu dydaktycznym ${ }^{64}$. Model przedstawiający wykład proces cywilny na końcu części ogólnej systemu jako ochrona praw prywatnych poprzedzający przedstawienie poszczególnych działów prawa prywatnego możemy odnaleźć w ostatnim wydaniu podręcznika R. Taubenschlaga ${ }^{65}$, gdzie część druga rozpoczyna się od czynności prawnych, przechodząc następnie do procesu rzymskiego ${ }^{66}$.

Taki układ przyjęto dziś również ostatnio w dziele współautorstwa W. Dajczaka, T. Giary i F. Longchamps de Bérier ${ }^{67}$, w którym wykład prawa procesowego i środków ochrony pozaprocesowej przedstawiono w rozdziale drugim, łącznie z czynnościami prawnymi, przed pozostałymi działami.

Zaprezentowaniem prawa procesowego przed wykładem instytucji prawa prywatnego materialnego charakteryzują się natomiast podręczniki: W. Osuchowskiego $^{68}$, K. Kolańczyka ${ }^{69}$, W. Bojarskiego ${ }^{70}$, A. Dębińskiego ${ }^{71}$, M. Żołnierczuka ${ }^{72}$, W. Rozwadowskiego ${ }^{73}$ oraz M. Kuryłowicza i A. Wilińskiego ${ }^{74}$.

K. Kolańczyk uzasadniał taki układ poważnymi względami historycznej i dydaktycznej natury"75. Ochrona procesowa w starożytnym Rzymie miała zindywidualizowany, a nie generalny charakter, który wynikał z pozostawienia uznaniu magistratury możliwości udzielenia jej obywatelowi rzymskiemu

${ }^{64}$ Przykładowo w podręczniku F. Zolla, Rzymskie prawo prywatne (Pandekta), T. II. Część ogólna, Warszawa-Kraków 1920 rozdział „O obronie stosunków prawnych” umieszczony został w części ogólnej, po pojęciu i istocie prawa oraz stosunkach prawnych. „Przepisy te należą do zakresu prawa publicznego i są przedmiotem osobnej nauki. Niektóre instytucje procesualne oddziaływały jednak według prawa rzymskiego na sam stosunek prawny, będący przedmiotem sporu i z tej przyczyny należy je tu wyłuszczyć”. Tamże, s. 88

${ }^{65}$ Rzymskie prawo prywatne, Warszawa 1955;

${ }_{66}$ Także w wydaniu drugim, opracowanym przez H. Kupiszewskiego ,Warszawa 1969. Wcześniej taką koncepcję prezentowały podręczniki polskie: Zielonackiego i Źródłowskiego, włoskie: Bonfantego, Arangio-Ruiza, Bettiego, Biondiego, Di Marzo, francuskie: Giffarda i Moniera, angielski Muirheada, radziecki Nowickiego-Peretierskiego, bułgarski Andriejewa. Zob. Kolańczyk K., (rec.), Nowy podręcznik..., s. 243-244.

67 Prawo rzymskie. Upodstaw prawa prywatnego, wyd. 2, Warszawa 2014; por. recenzję M. Kuryłowicza, który odnosi się krytycznie do faktu, iż proces cywilny „ukrył się skromnie w rozdziale 2 („Kształtowanie i ochrona praw prywatnych”)”. Recenzent zauważa, że zdeprecjonowanie ochrony praw prywatnych tylko do jednego podpunktu nie oddaje „szczególnej roli perspektywy procesowej w prawie rzymskim" i dynamiki procesowej rzymskiego prawa prywatnego. Zob. M. Kuryłowicz (rec.), Wojciech Dajczak, Tomasz Giaro, Franciszek Longchamps de Bérier, Prawo rzymskie. U podstaw prawa prywatnego, Warszawa 2009, Wydawnictwo Prawnicze PWN, s. 584, „Państwo i Prawo” 9/2011, s. 106

${ }_{68}$ Zarys rzymskiego prawa prywatnego, Warszawa 1962.

${ }^{69}$ Prawo rzymskie, wyd. 5, Warszawa 2005.

${ }^{70}$ Prawo rzymskie, Toruń 1983.

${ }^{71}$ Rzymskie prawo prywatne. Kompendium, wyd. 5. Warszawa 2011

${ }_{72}$ Zarys prawa rzymskiego, wyd. 2, Lublin 1992

${ }_{73}$ Prawo rzymskie. Zarys wykładu wraz z wyborem źródeł, Poznań 1991.

${ }_{74}$ Rzymskie prawo prywatne. Zarys wykładu, wyd. 6 Warszawa 2016.

${ }^{75}$ K. Kolańczyk, Prawo rzymskie, s. 103. 
w konkretnej sytuacji. Od tej decyzji zależało zatem posiadanie przez niego uprawnienia, będącego przedmiotem tej ochrony. Należy zatem, zgodnie z rozumowaniem Rzymian, w pierwszej kolejności uzyskać odpowiedź na pytanie jaki środek prawny ochrony przysługuje od pretora. Sam zaś przedmiot tej ochrony, rozumiany dziś jako uprawnienie, powinien być analizowany w dalszym porządku. Ten sposób przedstawienia procesu cywilnego jest najbliższe „rzymskiej myśli prawnej”. Takie właśnie ulokowanie rzymskiego procesu cywilnego w układzie podręczników oraz wykładzie wydaje ze wszech miar uzasadnione i wskazane również z racji propedeutycznych, przygotowuje bowiem studenta prawa do dalszych etapów studiów ${ }^{76}$.

Warto dodać, że w pojawiających się w ostatnich latach na rynku polskim podręcznikach i skryptach z zakresu prawa rzymskiego publicznego tematyka procesu cywilnego nie jest uwzględniana, co świadczy o utrwalonej już praktyce potwierdzającej zasadność omawiania go przy przedstawianiu instytucji prawa prywatnego ${ }^{77}$.

\section{Podsumowanie}

W konkluzji należy przypomnieć, że w podziałach prawa dokonywanych przez starożytnych Rzymian tylko Gaius w swej systematyce podręcznikowej wyróżnił prawo procesowe. Ta klasyfikacja została także przejęta przez „Instytucje” justyniańskie. Z racji praktycznych normy procesowe były natomiast główną treścią edyktu pretorskiego, który odegrał największą rolę w rozwoju rzymskiego prawa procedury cywilnej i systematyzacji norm jej dotyczących. Utylitaryzm i specyfika tego układu nie mogła jednak mieć przełożenia na późniejszą systematykę prawa, chociaż wzorowała się na niej komisja układająca justyniańskie Digesta. Poza tym miejsce rzymskiego procesu cywilnego, podobnie jak

${ }^{76}$ Zdaniem niektórych, umieszczenie odrębnej części poświęconej rzymskiemu procesowi cywilnemu obok rozdziałów dotyczących prawa materialnego, daje studentowi „może nieco „pandektystyczny obraz" sztucznie wyodrębnionych działów prawa rzymskiego prywatnego, w tym rzymskiego postępowania cywilnego”, ale „sprawdza się w codziennej dydaktyce”. Zob. K. Amielańczyk, U podstaw prawa prywatnego..., s. 160. Por także opinie K. Kolańczyka i E. Pòlaya o miejscu prawa procesowego w podręcznikowej systematyce prawa rzymskiego w socjalizmie: K. Kolańczyk, Über den Bildungswert..., s. 286-288; E. Pòlay, Das römische Recht in den sozialistischen Ländern, „Labeo“ 13 (1967), s. 365.

${ }^{77}$ Rzymskie prawo publiczne, red. B. Sitek, P. Krajewski, Olsztyn 2004, Rzymskie prawo publiczne, Olsztyn 2006; J. Zabłocki, A. Tarwacka, Publiczne prawo rzymskie. Skrypt z wyborem źródeł, Warszawa 2005 oraz Publiczne prawo rzymskie, Warszawa 2011; T. Palmirski, Publiczne prawo rzymskie. Zarys wykładu. Skrypt dla studentów prawa i administracji, Kraków 2006; A. Dębiński, J. Misztal-Konecka, M. Wójcik, Prawo rzymskie publiczne, Warszawa 2010; K. Wyrwińska, Civis Romanus sum. Rzymskie prawo publiczne. Wybrane zagadnienia, Kraków 2015. 
cała systematyzacja prawa, nie były dla rzymskich prawników przedmiotem szczegółowych dociekań. Trzeba zauważyć, że podobnie jest również dzisiaj, gdy kwestia ta największe znaczenie ma właściwie dla realizacji celów natury dydaktycznej - w podręcznikach i wykładach $z$ tego przedmiotu. $Z$ tychże racji należy przyjąć, że prawo rzymskiego procesu cywilnego mieści się w ogólnym pojęciu „prawo rzymskie”, zauważając jednocześnie utrwalony już pogląd, że dział ten ma zasadniczo charakter publicznoprawny, zawierającym również elementy prywatne. Ze względu jednak na wspomniane wyżej przesłanki dydaktyczne oraz wpływ na rozwój rzymskiego prawa prywatnego, przy okazji omawiania tej problematyki, przedstawia się także ochronę praw prywatnych i taką właśnie koncepcję należy uznać za słuszną i celową. Pozostaje przy tym żywić nadzieję, że wykładowcy prawa rzymskiego i autorzy podręczników do tego przedmiotu, mimo szczupłej liczby godzin kształceniowych i trudności dydaktycznych, jakie niesie ze sobą sposób przedstawienia współczesnym studentom prawa, rzymskiego procesu cywilnego, będą w stanie urzeczywistniać przekonanie K. Kolańczyka, iż można przybliżyć tę skomplikowaną materię jasno, żywo i rzeczowo na tyle, by uzyskać właściwe rezultaty kształceniowe i przekazać przy tym młodym prawnikom humanistyczne wartości ${ }^{78}$.

\section{Wykaz literatury:}

Amielańczyk K., U podstaw prawa prywatnego. "Rzymski proces cywilny" i jego zasady. (Uwagi na marginesie nowego podręcznika prawa rzymskiego W. Dajczaka, T. Giaro i F. Longchampsa de Bérier, "Gdańskie Studia Prawnicze”, T. XXIV, 2010, s. 157-175;

Amielańczyk K., Zasada skargowości i zakaz orzekania ponad żądanie stron w procesie rzymskim, "Gdańskie Studia Prawnicze" t. 33, 2015, s. 33-46;

Bartošek M., Římské právo a socialistická spoločnost, [w:] „Rozpravy Československé Akademie Véd - Řada Společenských Věd" 76 (1966), z. 12, Československé Akademie Véd, Praha 1966;

Bartošek M., Třidni základy řimského procesního práva, "Právněhistorické Studie" 14, Praha 1969;

Betti E., Processo civile (Diritto Romano), [w:] Novissimo Digesto Italiano, a cura di A. Azara, E. Eula, vol. XIII, Torino 1966, s. 1099-1120;

Bojarski W., Prawo rzymskie, Toruń 1983;

Dajczak W., Giaro T., Longchamps de Bérier F., Prawo rzymskie. U podstaw prawa prywatnego, Warszawa 2014;

Dębiński A., Rzymskie prawo prywatne. Kompendium, wyd. 5. Warszawa 2011;

Dębiński A., Misztal-Konecka J., Wójcik M., Prawo rzymskie publiczne, Warszawa 2010;

Gintowt E., Rzymskie prawo prywatne w epoce postępowania legisakcyjnego, Warszawa 1960 (wydanie wznowione 2005);

Jaworska-Stankiewicz R., "Qua actione tenetur?" actio a prawo podmiotowe w prawie rzymskim, [w:] Prawa podmiotowe - pojmowanie w naukach prawnych. Zbiór studiów, red. I. Ciapała, K. Flaga-Gieruszyńska, Szczecin 2006, s. 325-332;

Jędrejek G., Powstanie, rozwój i znaczenie niemieckiej szkoły historyczno-prawnej, „Summarium” 32 (52) 2003, s. 130-158;

${ }^{78}$ K. Kolańczyk, Über den Bildungswert..., s. 295. 
Jędrejek G., Prawo rzymskie a systematyka prawa prywatnego w Polsce w XIX-XX wieku, [w:] Starożytne kodyfikacje prawa, Lublin 2000, s. 199-242;

Jonaitis M., Žalènienè I., The concept of bar and fundamental principles of an advocate's acitivity in Roman Law, „Jurisprudence” 2009, 3 (117), s. 299-312;

Jörs P., Kunkel W., Wenger L., Römisches Recht, Berlin-Heidelber-New York-London-Paris-Tokyo 1986;

Kaser M., Hackl K., Das römische Zivilprozessrecht (zweite Aufl.), München 1996;

Kelly J. M., Studies in the Civil Judicature of the Roman Republic, Oxford 1976;

Kodrębski J., Sabinianie i Prokulianie. Szkoły prawa w Rzymie wczesnego cesarstwa, Łódź 1974;

Kolańczyk K., (rec.), Nowy podręcznik rzymskiego prawa prywatnego. Uwagi w zwiq̨zku z praca Wacława Osuchowskiego, Zarys rzymskiego prawa prywatnego, Warszawa 1962, PWN, ss. 553, "Czasopismo Prawno-Historyczne" 1965, t. XVII, z. 1, s. 231-255;

Kolańczyk K., O pochodzeniu i stanowisku społecznym jurystów rzymskich, „Czasopismo Prawno-Historyczne" 7 (1955), z. 1, s. 227-284;

Kolańczyk K., Prawo rzymskie, wyd. 5, Warszawa 2005

Kolańczyk K., Über den Bildungswert der römischen Zivilprozesslehre für den sozialistischen Juristen, [w:] „Acta Univ. Szegediensis. Acta Juridica et Politica”, t. XXVII, z. 22, Szeged 1970, s. 292-293; por. M. Kaser, K. Hackl, Das römische Zivilprozessrecht (zweite Aufl.), München 1996, s. 279-299;

Kubiak P., Kilka uwag o znajomości prawa u mówców sq̨dowych republikańskiego Rzymu, „,Krakowskie Studia z Historii Państwa i Prawa" 2015, t. 8, z. 1, s. 1-24;

Kupiszewski H., Prawo rzymskie a współczesność, Warszawa 1988;

Kuryłowicz M. (rec.), Alfons Bürge, Römisches Privatrecht: Rechtsdenken und gesellschaftliche Verankerung; eine Einführung, Wissenschaftliche Buchgesellschaft, Darmstadt 1999, stron XII, 248, indeksy, "Czasopismo Prawno-Historyczne" (52) 2000, z. 2., s. 361-365.

Kuryłowicz M., De publicis iudiciis. Instytucje justyniańskie o postępowaniach sq̨dowych publicznych, [w:] Problemy stosowania prawa sądowego. Księga ofiarowana profesorowi Edwardowi Skrętowiczowi, Lublin 2007, s. 561-572;

Kuryłowicz M., "Eminentissimo viro iuris consulto..." Rzymscy juryści w tekstach epigraficznych, „Studia luridica Lublinensia" vol. XXV, 3, 2016, s. 497-509;

Kuryłowicz M., Prawo rzymskie. Historia-Tradycja-współczesność, Lublin 2013;

Kuryłowicz M., Wiliński A., Rzymskie prawo prywatne. Zarys wykładu, wyd. 6, Warszawa 2016;

Kuryłowicz M. (rec.), Wojciech Dajczak, Tomasz Giaro, Franciszek Longchamps de Bérier, Prawo rzymskie. U podstaw prawa prywatnego, warszawa 2009, Wydawnictwo Prawnicze PWN, s. 584, „Państwo i Prawo" 9/2011, s. 105-108;

Kuryłowicz M., Wokół pojęcia „aequitas" w prawie rzymskim, „Studia luridica Lublinensia” 15, 2011, s. 15-27;

Kupiszewski H., Litis contestatio, "Czasopismo Prawno-Historyczne” 1963, t. 13, z. 1, s. 243-265;

Litewski W., Jurysprudencja rzymska, Kraków 2000;

Litewski W., "Litis contestatio" en obligations solidaires passives dans les ", bonae fidei iudicia" en droit Romain classique, "Revue Historique de Droit Français et Étranger” 54, 1976 nr 2, s. 149-175;

Litewski W., L'effet libératoire de la "litis contestatio" dans les obligations solidaires actives en droit de Jusinien, „Labeo" 24, 1978, s. 301-316;

Litewski W., Rzymskie prawo prywatne, Warszawa 1990;

Litewski W., Rzymski proces cywilny, Kraków 1988;

Litewski W., Rzymski proces karny, Kraków 2003;

Litewski W., Słownik encyklopedyczny prawa rzymskiego, Kraków 1998;

Litewski W., Studia nad rzymskim postępowaniem kognicyjnym, Kraków 1971;

Litewski W., Wybrane zagadnienia rzymskiej apelacji w sprawach cywilnych, Kraków 1967

Łyczywek R., Marek T. Cyceron - adwokat rzymski, „Palestra” 4/9 (33) 1960, s. 75-91

Metzger E., An Outline of Roman Civil Procedure, „Roman Legal Tradition” vol. 9 (2013), s. 1-30; 
Metzger E., Roman Judges, Case Law and Principles of Procedure, Roman Law Resources (www. lusCivile.com), s. 19-35;

Mossakowski W., Elementy cywilnoprawne rzymskich skarg cywilnych, [w:] Honeste vivere. Księga pamiątkowa ku czci Profesora Władysława Bojarskiego, Toruń 2001, s. 133-138

Nowacki J., Prawo publiczne-prawo prywatne, Katowice 1992;

Osowy P., Powództwa o ukształtowanie stosunku prawnego, Warszawa 2015;

Palmirski T., Publiczne prawo rzymskie. Zarys wykładu. Skrypt dla studentów prawa i administracji, Kraków 2006

Pogonowski P., Znaczenie paremii rzymskich dla współczesnej procedury cywilnej, [w:] Starożytne kodyfikacje prawa, Lublin 2000, s. 187-198;

Pòlay E., Das römische Recht in den sozialistischen Ländern, „Labeo" 13 (1967), s. 361-375.

Rozwadowski W., Nauczanie prawa w państwie rzymskim, "Czasopismo Prawno-Historyczne” 55, 2003, z. 1, s. 9-28;

Rzymskie prawo publiczne, red. B. Sitek, P. Krajewski, Olsztyn 2006;

Schulz F., Classical Roman Law, Oxford 1951;

Sondel J., Słownik łacińsko-polski dla prawników i historyków, Kraków 1997;

Szymoszek E., Prawo podmiotowe w nauczaniu Stanisława Wróblewskiego, [w:] Honeste vivere. Księga pamiatkowa ku czci Profesora Władysława Bojarskiego, Toruń 2001, s. 257-268;

Szymoszek E., Uprawnienie-roszczenie-skarga według Stanisława Wróblewskiego, [w:] Valeat aequitas. Księga pamiątkowa ofiarowana Księdzu Profesorowi Remigiuszowi Sobańskiemu, red. M. Pazdan, Katowice 2000, s. 453-467

Święcicka P., Prawo jurysprudencyjne jako prawniczy dyskurs argumentacyjny: (zarys problematyki), "Zeszyty Prawnicze" 11.1 (2011), s. 317-338;

Taubenschlag R., Rzymskie prawo prywatne, Warszawa 1955;

Wenger L., Institutes of the Roman Law of Civil Procedure, transl. by O. Fisk, New York 1955;

Wojciechowski R., Arbiter w prawie rzymskim, [w:] Postępowanie polubowne w dziejach, Wrocław 2006, s. 17-25;

Wolff H. J. (rec.), Institutes of the Roman Law of Civil Procedure. Revised Edition, by Leopold Wenger, translated by Otis Harison Fisk, with an introduction by Roscoe Pound. Veritas Press, New York, 1940. PpXXX, 440. \$ 6.00, "Louisiana Law Review”, vol. 5, nr 2, 1943, online: http://digitalcommons. law.Isu.edu/cgi/viewcontent.cgi?article=1374\&context=lalrev

Wołodkiewicz W. [rec.], Gaio nel suo tempo. Atti del Simposio romanistico, Biblioteca di Labeo, III, Napoli "Jovene 1966, s. VII+161, "Czasopismo Prawno-Historyczne" 21, 1969, z. 1,

Wołodkiewicz W., Zabłocka M., Prawo rzymskie. Instytucje, wyd. 6, Warszawa 2014;

Wyrwińska K., Civis Romanus sum. Rzymskie prawo publiczne. Wybrane zagadnienia, Kraków 2015;

Zabłocka M., Romanistyka polska po Il wojnie światowej, Warszawa 2002;

Zabłocka M., Romanistyka polska w pierwszym dziesięcioleciu XXI wieku, Warszawa 2013;

Zabłocka M., Zabłocki J., Ustawa XII Tablic.: tekst, tłumaczenie, objaśnienia, Warszawa 2000;

Zabłocki J., Tarwacka A., Publiczne prawo rzymskie. Skrypt z wyborem źródeł, Warszawa 2005;

Zabłocki J., Tarwacka A., Publiczne prawo rzymskie, Warszawa 2011;

Żołnierczuk M., Zarys prawa rzymskiego, wyd. 2, Lublin 1992.

\section{Streszczenie}

Z problematyką rzymskiej procedury cywilnej wiąże się pojawienie licznych i interesujących kwestii oraz pytań problematycznej natury. Przykładowo, pewne wątpliwości może wzbudzić publiczny czy też prywatny charakter tego postępowania. Artykuł przedstawia pewne wybrane kontrowersyjne problemy związane z miejscem procesu cywilnego w systematyce prawa rzymskiego. System prawa procesowego w antycznym Rzymie przechodził dynamiczną ewolucję aż do czasów Justyniana. 
Najistotniejsze, z punktu widzenia dydaktycznego wydaje się przedstawienie, godnego uznania i misternie skonstruowanego, podobnie jak całe rzymskie prawo prywatne, rzymskiego procesu formułkowego. Rzymianie nie dokonali całościowej kodyfikacji procesu cywilnego, nie był on także dla nich zasadniczo odrębnym działem prawa. Tematyka rzymskiej procedury cywilnej, ze względu na swój doniosły wpływ na rozwój i kształt rzymskiego prawa prywatnego, zawarta jest zazwyczaj w jednym z rozdziałów podręczników prawa rzymskiego. Właściwy sposób przedstawienia tego działu powinien pomóc studentom w zrozumieniu historycznego podłoża współczesnych kierunków rozwoju procedury cywilnej i prawidłowej ocenie humanistycznych wartości rzymskiego procesu cywilnego.

Słowa kluczowe: rzymski proces cywilny, ochrona praw prywatnych, systematyka prawa rzymskiego.

\section{Position of civil procedure in the sistematization of Roman law}

\section{Summary}

There are numerous and highly interesting problems and questions arising from the Roman law of civil procedure. We might have, for instance, some doubts becouse of public or private character this procedure. The article presents some controversial and selected issues considered with position of civil procedure in the sistematization of Roman law. The system of the law of procedure in ancient Rome had its own dynamic evolution down to Justynian period. The most important for the didactic purpose seems to be the Roman formulary procedure, which was intricate an has attracted the same admiration as Roman private law. The Roman had never gathered this procedure sistematically or studied it as an autonomous subject. The Roman law of civil procedure, in spite of its fundamental influence on the development and structure of the Roman system of private law, is usually confined to a chapter in textbooks on Roman law. The right way of enunciate this part should helps the students to understand the historical background of present trends in civil procedure and to appraise the humanistic factors working in them.

Keywords: Roman civil procedure (process), sistematization of Roman law. 